Ekaterina V. Lebedeva ${ }^{1 *}$, Dmitry V. Mikhalev ${ }^{2}$, Josŭ E. Novoa Jerez ${ }^{3}$,

Mariya E. Kladovschikova ${ }^{4}$

${ }^{1}$ Institute of Geography Russian Academy of Sciences, Moscow, Russia;

Staromonetny per., 29, 119017; Tel: +7-910-416-66-89, Fax: +7-495-959-0033,

e-mail: Ekaterina.lebedeva@gmail.com,

*Corresponding author

2 Faculty of Geography, Lomonosov Moscow State University, Moscow, Russia; Leninskie Gory, 1, 119991; Tel: +7-903-259-05-92, e-mail: mikhalev@kapitelproekt.ru 3 University of La Serena - CEAZA, La Serena, Chile, Colina El Pino s/n, Casilla 599;

Tel: 056-51-204396, e-mail: jnovoa@userena.cl

${ }^{4}$ Institute of Geography Russian Academy of Sciences, Moscow, Russia;

Staromonetny per., 29, 119017; Tel: +7-926-577-40-43, e-mail: masisuanka@mail.ru

\title{
GEOMORPHOLOGIC HAZARD AND DISASTERS IN THE SOUTH AMERICAN ANDES ${ }^{1}$
}

ABSTRACT. Geological-and-tectonic and physiographical features of the South American Pacific coast caused high intensity of morpholitogenesis including disaster-like way of some geomorphologic processes. Their complex, interaction, and intensity of conductive factors increase the risk of disaster. The Andean terrain morphology and rock lithology, precipitation type, and vegetation status are the main drivers that influence the character and high potential intensity of the geomorphologic processes. The enormous hydrometeorological events, frequent seismic shocks, volcanic eruptions, and human impact cause disasters development. A schematic map of disaster and hazardous processes for the Central sector of Andes was compiled. 16 areas with different spectra of the dominant catastrophic processes were identified. The South American Andes extension allows drawing out principles of geomorphologic disasters of these continental marginal mountains in various natural zones from temporal to subequatorial latitudes, which are characterized by the individual unique heat-moisture rate, which governs both typical and extreme geomorphologic processes. An important feature of the

${ }^{1}$ The reported study was partially supported by RFBR, research project №12-05-00900 a study area is the asymmetric distribution of geomorphologic processes within coastal and inland slopes of the mountain system, as well as latitudinal zoning of this distribution.

KEY WORDS: Geomorphologic hazard and disasters, South American Andes, intensity of geomorphologic processes, seismic and volcanic activity, unbalanced precipitation, mass movements of debris

\section{INTRODUCTION}

Geomorphologic disaster is considered to be a process which unbalances the geomorphologic system and leads to step or sudden change of its state [Aleksandrov, 1996; Ananiev, 1998; Phillips, 2011]. This change is the result of accumulation of substance and/or energy critical mass. Any process in one or another regional range could manifest a disaster, however, in this case its quickness, development, and impact (e.g. the volume of displaced material) would be incomparable to ground processes, i.e. common processes within a given territory. Geomorphologic disasters could be caused by immediate (e.g. volcanic eruption) or step-by-step (sea-level change) environmental transformations driven by 
natural and human factors (e.g. slope plant destruction).

Also, there are geomorphologic hazards (or extreme, critical display of processes) that coincide with short-run but serious deviation from the norm of typical (ground) processes and cause the transformation of certain elements in geomorphologic system [Ananiev, 1998; Korotkiy et al., 2011].

Actually, these specific environments act as some "triggers": they set and/or promote geomorphologic processes that change ground values for critical situations or disasters. These could be endogenous (e.g. earthquakes), exogenous (extreme volume or rate of precipitation, etc.), and humancaused factors and their combination.

Obviously, the character and rate of process activation largely depend upon specific nature of terrain: e.g., common ground mountainous processes may be disastrous for plain lands. Also, resistance of terrain complexes to natural and human-caused processes is of great concern. Lithological composition of rocks, vegetation, weathering kind, precipitation regime, and other physical-and-geographical conditions are of great importance. It is especially true for high contrast terrain territories with large number and high speed of terrain-forming processes where disaster risk is very high and causes significant damage to population and economic activity. The development of vulnerable regions and application of complex production technology increase the risk of natural hazard.

According to Swiss Reinsurance Co [http:// inosmi.ru/infographic/20111226/181319543], global financial loss from natural disaster amounted to $\$ 226$ billion in 2010 and a record figure of $\$ 350$ billion in 2011 . Finam. info states that all disasters in 2010 caused nearly 304 thousand deaths worldwide maximal since 1976. Haiti earthquake is topping the list of the most lethal disasters more than 225,5 thousand deaths. The most expensive natural disaster is associated with the Chinese earthquake with loss of $\$ 30$ billion. According to World Bank, the Japanese earthquake of a 9,0 magnitude followed by the tsunami on March 11, caused the maximal loss of \$122-235 billion [http://finam.info/need/news2478800001]. Therefore, the study and prediction for both natural and anthropogenic catastrophic geomorphic processes is a very important task.

Continental marginal mountains, including the South American Andes, are characterized by supreme terrain contrast, mosaic structure of surface and crust, and rich complex of modern endogenous processes - volcanism, seismicity, and vertical movements [Tectonic Evolution, 2000; The Andes, 2006; Charrier R. et al., 2013, etc.]. Climate patterns of these territories caused by ocean and continental air masses interaction also play the significant role in exogenesis. So given regions are characterized by diverse variety of terrainforming processes, their high speed, and, sometimes, disasters.

Stress conditions of geomorphologic systems and processes, i.e., their potential disbalance [Gotvanskiy, Lebedeva, 2010; Lebedeva, 2013] require research of continental marginal mountains of areal and temporal specific nature of geomorphologic hazards and disasters. This issue is addressed in this paper.

The paper is based on the authors' field study records, results of photo- and satellite interpretation, literature, and map data analysis.

\section{MAIN GEOLOGICAL-AND- GEOGRAPHICAL FEATURES OF THE REGION}

The total length of the South American Andes is 9000 km; average altitude is 4000 m; and top altitude - Aconcagua - is 6962 $\mathrm{m}$. There are two or even three subparallel mountain ranges within different areas. The total width is $500 \mathrm{~km}$; in the Central Andes (between $18^{\circ}$ and $20^{\circ} \mathrm{S}$ ), where high-altitude 
Altiplano plateau is situated, it reaches $750 \mathrm{~km}$. This paper highlights the Central (Peruvian and Bolivian) Andes, the Southern (Chile-and-Argentine) Andes, and also the southern part of the Northern (Ecuadorianand-Venezuelan) Andes.

The South American Andes, primary, is the result of Alpine orogeny; tectonic movements continue until present. Faults, volcanism, and recent lifting played an important role in the alpine fold-block structure forming. The main morphostructures are characterizes by submeridional extension, while crossover tectonic dislocations are indefinite [Tectonic Evolution, 2000, etc.].

High seismicity is indicative for young mountains as the Andes are. About 570 earthquakes with magnitude of more than 7 and focus of up to $100 \mathrm{~km}$ were instrumentally recorded before 2013 [http:// www.ncedc.org/anss/catalog-search.html].

Coastal parts of Southern Columbia and Northern Ecuador, Central and Southern Peru, and coastal Chile to the north of Valdivia are most seismic and characterized by earthquakes with a magnitude of 8 and more. Detailed analysis of earthquakes frequency and energy distribution in the Pacific part [Levin, Sasorova, 2009] showed that the maximal seismic activity corresponds to two narrow latitudinal intervals, i.e., 20$25^{\circ} \mathrm{S}$ and $30-35^{\circ} \mathrm{S}$. In these areas, the number of earthquakes and their energy are an order of magnitude greater than, for example, in the $40-45^{\circ} \mathrm{S}$ interval. The Eastern Andes are much less seismic, though even there, specifically, near Mendoza, San-Juan, and Salta (Argentina), the earthquakes reach 7-8 points on the Richter scale; these cities were destroyed many times in the past [Alvarado, Beck, 2006].

A seismofocal zone is traced along the west side of the South America; it is separated by lateral faults into several sections with unlike steep dip. Easy dip sections (the Peruvian and the Central Chilean Andes) are characterized by lack of quaternary and modern volcanism, while steep dip sections (the Central and the
South volcanic mountains) are characterized by intense modern volcanism [Zhidkov, 1985; Cembravo, Lara, 2009; Tilling, 2009]. Three volcanic zones are located in the Andes with more than 200 active volcanoes - 197 of the Holocene age and 5 of the Pleistocene age with modern thermal activity [http://www. volcano.si.edu/world].

The Andes is a continental divide and most important South American climatic barrier that separates the Pacific and the Atlantic affected areas. Situated within 5 climatic belts (equatorial, subequatorial, tropical, subtropical and temperate) it is characterized by a sharp contrast in precipitation on the eastern and western slopes [Lukashova, 1958; Garreaud, etc., 2009]. The western slopes have low moisture availability between $5^{\circ}$ and $28^{\circ} \mathrm{S}$ : while the northern part of the Central Andes (Peru) catches 200-250 $\mathrm{mm}$ annually, this amount decreases and does not exceed $50 \mathrm{~mm}$ annually in places southward (north of Chile) - the Atacama desert lies here - the most dry desert in the world. Desert landscapes are traced up to 3000 m A.S.L. and higher. Semidesert or steppe landscapes prevail above 3000 m (within the Altiplano plateau) - so-called dry puna with more than $250 \mathrm{~mm}$ annual rainfall only occasionally. Softening action of Lake Titicaca within surrounding lands mitigates temperature fluctuations and makes them less contrast compared to other parts of plateau. The eastern slopes of the Andes catch 3000-6000 mm annual rainfall brought from the Atlantic Ocean [Garreaud et al., 2003]. As for modern glaciation, it is too irregular because of the various climatic environments. At this rate, the snow-line in Ecuador and Peru ranges from 4000 to 5000 $\mathrm{m}$ and rises to 6300-6500 $\mathrm{m}$ in the Altiplano with its dry air and high insolation and winds - e.g. being at the top in the world [Troshkina, Kondakova, 2000].

Subtropical climate of the Chile-andArgentine Andes (between $28^{\circ}$ and $38^{\circ} \mathrm{S}$ ) brings more moisture compared to the subequatorial and tropical zones. Southwards, annual rainfall values increase 
from 350 (Santiago) to $750 \mathrm{~mm}$ (Valdivia) within western slopes, while eastern slopes become more rainless. Increasing south rainfall, along with a reduction in mean annual temperatures, leads to a gradual lowering of the snow line and valley glaciers are forming there.

Near $37-38^{\circ}$ S, subtropical climate of western slopes gradually transitions to oceanic climate of middle latitudes: annual amount of rainfall increases; in-season humidity differences decrease. Southward $37^{\circ} \mathrm{S}$, eastern slopes catch more precipitation although precipitation is lower than that of the western. Precipitation of the southernmost part of the Andes - Tierra del Fuego (up to $3000 \mathrm{~mm}$ annual) bears is more like drizzle and snow in mountains. The Patagonian Andes environment is most favorable for glacier formation. The snowline decreases to 1000-1200 m; areas of the continental ice sheet are located here - the South and North Patagonian glacier plateaus with extended outlet glaciers.

\section{FACTORS THAT CAUSE EXTREME EVENTS AND DISASTERS}

Therefore, various parts of the Andes are situated in different geological-and-tectonic and physiographic conditions that impact geomorphologic processes, including geomorphologic hazard and damage.

Active "provocateurs" of extreme (critical) geomorphologic situations are seismic and volcanic processes. Earthquakes provoke large movements of debris within slopes (Fig. 1) with volume equal to several cubic kilometers, glacial slides, avalanches and mudflows, and volcanic processes.

During seismic events, fractured zones "come to life" first - zones of rock breaking and advance rock fracturing; often, vertical movements of the land mass are recorded [Enman, 1973; The Andes, 2006]. The zones of big faults intersection - the so-called "morphostructural knots" [Zhidkov, 1985; Rantsman, Glasko, 2004] - are of high activity.
Earthquakes with focuses in coastal areas or sea shelf provoke tsunami. Coastal areas of the Central Chile and Central and Northern Peru are most vulnerable. For example, near La Serena city (the Koquimbo bay, Chile) 37 tsunami were recorded during 1562-1995 with a peak of $14 \mathrm{~m}$ (1922) [Novoa et al., 1995]. The 1996 tsunami affected $400 \mathrm{~km}$ along the Peruvian coast - from Chimbote in the north to San-Juan in the south. It was found that the 24-26 $\mathrm{m}$ high destructive tsunami were provoked by the earthquakes in 1586, 1687, 1746, and 1828 within this coastal area. Numerous tsunami in this area are explained by vertical movements of the crustal blocks related to the Nazka plate subduction under the South American plate [Pararas-Carayannis, 1974]. However, distant seismic events sometimes influence the coast: tsunami of $2 \mathrm{~m}$ high, which have destroyed the La Serena city seafront (12.03.2011), were caused by the Japanese earthquake.

Volcanic activity can also cause the earth tremor and tsunami, but in mountainous areas, hazards are related to ash falls, lava floods, the lahars, and debris avalanches. The most powerful eruption of the region took place in 1600 in Peru: the total volume of Huayanaputina pyroclastic material reached near 11 cubic kilometers with $1000 \mathrm{~km}$ of blow radius. The subsequent lahar passed more than $100 \mathrm{~km}$ and reached the Pacific Ocean. Two eruptions of total volume 9,5 and 8 cubic kilometers took place in Chile in the XXth ${ }^{\text {th }}$ century [Tilling, 2009].

But even relatively small eruptions could be damaging, like the Nevado del Ruiz (Columbia, 5398 m) eruption in 1985 with the total volume of about 0,05 cubic kilometers. Lahars (mudflow with volcanic genesis) were formed due to the melting of snow cover and the glacier; one of them destroyed Armero city, causing more than 23 thousand deaths. Lahars traces were recorded on 32 active volcanoes; notably, the Cotopaxi (Ecuador) volcano has 22 traces of lahars that took place during the $\mathrm{XV} \mathrm{I}^{\text {th }}-\mathrm{XI} \mathrm{X}^{\text {th }}$ centuries [Perov, 2012]. 

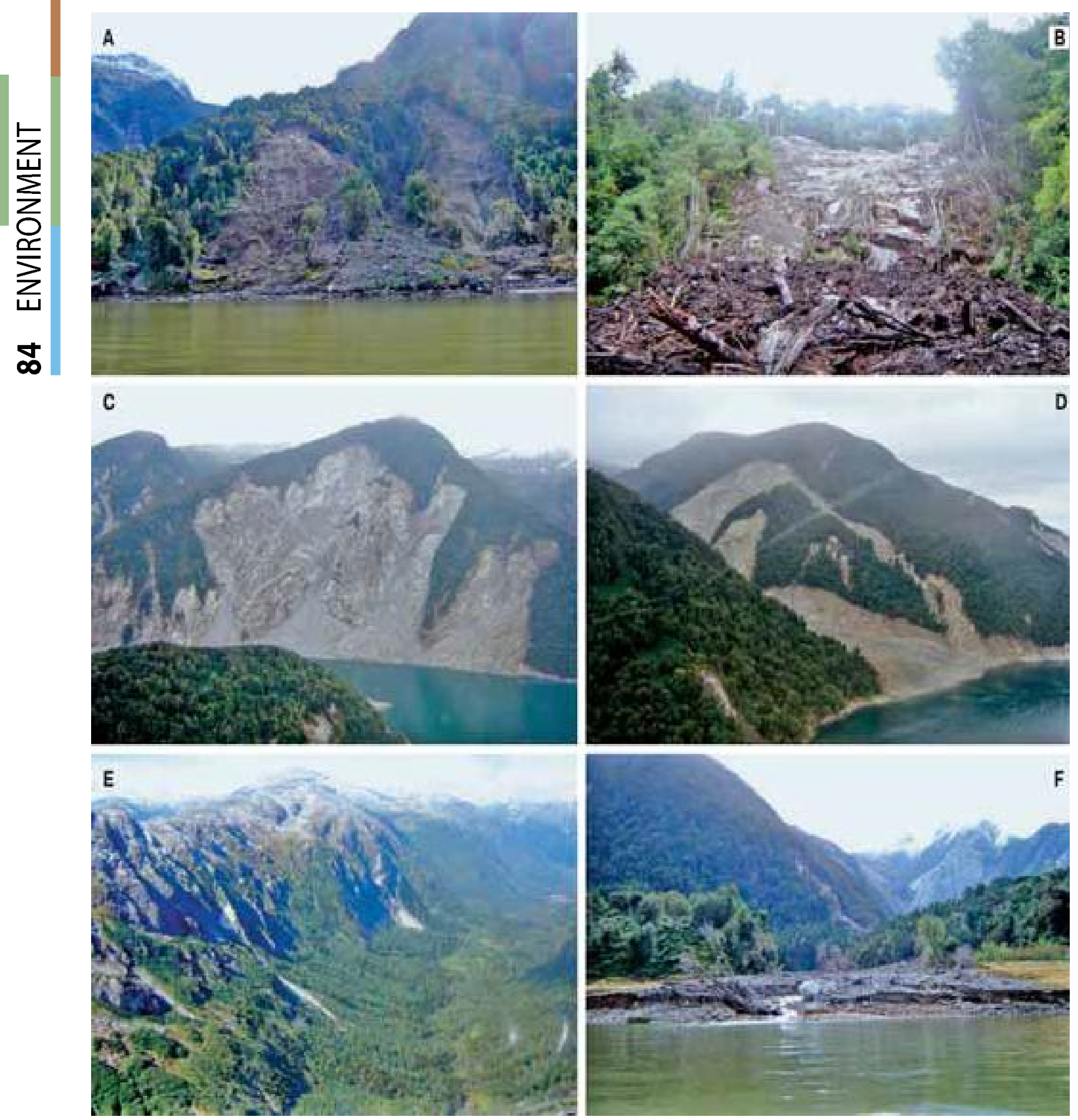

Fig. 1. Examples of the different types of earthquake-induced landslides in the Aysén Fjord area (Chile).

A - shallow soil slides, $B$ - shallow soil-rock slide, $C$ - rock slide in front of Mentirosa Island, $D$ - rock slide and avalanche in Punta Cola area, E - rock falls, F- debris flow (Sepulveda et al., 2010)

Annually, several eruptions of different power usually take place in the Andes. For example, eruption of the small Chaiten volcano (1122 m, Chile) lasted almost two years: it started in May of 2008 after more than 9 thousand years of inactivity. The estimated volume of pyroclastic material was 0,17 cubic kilometers; slope lava and pyroclastic flows formed. There were also 3 lahars; one of them destroyed most part of the same-name town situated in the Rio-
Blanca River mouth (Fig. 2); however, citizens were evacuated.

Geomorphologic instability and active terrain-forming processes are caused by the topography itself - high altitude and highly dissected steep-side mountains. The range of amplitudes within the studied territory, from the coast to the water-divide part of the Andes, is extremely high: $7000 \mathrm{~m}$ for $150 \mathrm{~km}$ in the central part of Chile and more 


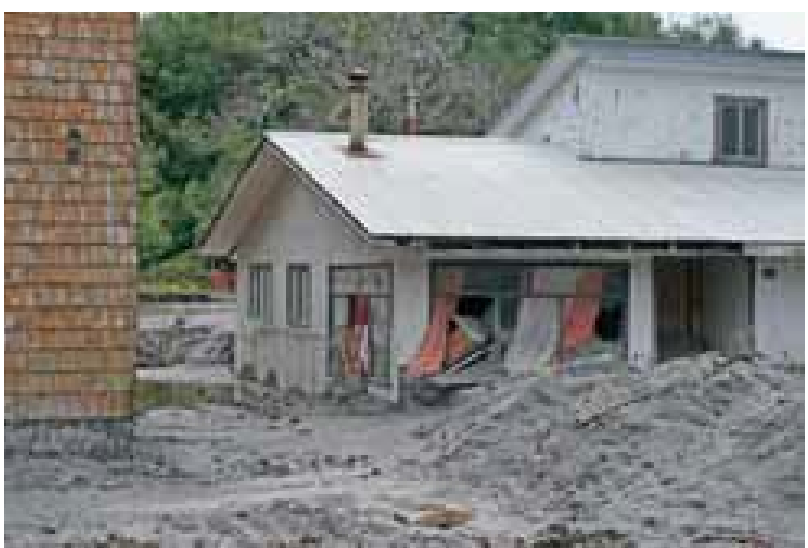

Fig. 2. Lahar traces on the Chaiten streets (Chile, February 2010).

Hereinafter all photos without author index belong to $\mathrm{E}$. Lebedeva

than $6000 \mathrm{~m}$ for $100 \mathrm{~km}$ in Peru. Two to three kilometers of gullies of some river valleys (both - western and eastern slopes of the Andes) cause the split of the interstream areas, rock-falls, instability of valley slopes to even long-distance earthquakes [Ufimtsev, 2011]. Deep valley cut-ins can provoke long-living landslides in hydrologically and lithologically favorable environment, e.g., the so-called "Lluta collapse" in the northern part of Chile, where landslides have been active during 2,5 million years [Novoa, 2013].

Other significant exogenous drivers are temperature and moisture conditions within the Andes slopes [Garreaud, 2009]. Air temperature decreases and precipitation increases with altitude in the same climatic zone. For example, precipitation increases from 0 to $400 \mathrm{~mm} /$ year in the Northern Chile $\left(18-22^{\circ} \mathrm{S}\right)$ and to $700 \mathrm{~mm} /$ year in the Southern Peru (14-18 $\mathrm{S}$ ) when moving from the coast to 4500 M.A.S.L. [Garreaud et al., 2003]. Southward in the Aconcagua and Maipo River basins $\left(32-34^{\circ} \mathrm{S}\right)$, with every thousand meters of altitude, precipitation increases by one-half [Garreaud, 1992]. For example, precipitation increases from 240 to $1000 \mathrm{~mm}$ with altitude in the Aconcagua River basin [Golubev, 1969]. Each latitudinal and longitudinal zone is characterized by specific altitudinal zonality range. This is reflected not only in spatial change of natural complexes, but also in change of the exogenous processes specific for these complexes and, above all, of the consequences of these processes [Montgomery et al., 2001].

Topography and temperature and humidity conditions greatly influence gravitation, fluvial, glacial, eolian, and other geomorphologic hazards and disasters. This is reflected on the schematic map of modern exogenous processes in the area between the Ecuadorian and central part of the ChileArgentine Andes [Kladovschikova, 2008].

In high humidity conditions, both fluvial and slope processes are active due to surface waterlogging: landslides, mudslides, solifluction, and mudflows. Mudflow hazards are indicative for the most part of the Andes (Fig. 3). The prevalent type of mudflow northward of $45^{\circ} \mathrm{S}$ is rain mudflows, whereas, southward and near the modern glacial mass, it is snow and glacial mudflows, and near active volcanoes, it is lahar mudflows [Perov, 2012]. The period of the most mudflow hazard within 6-30 S in the Andes is local summer;

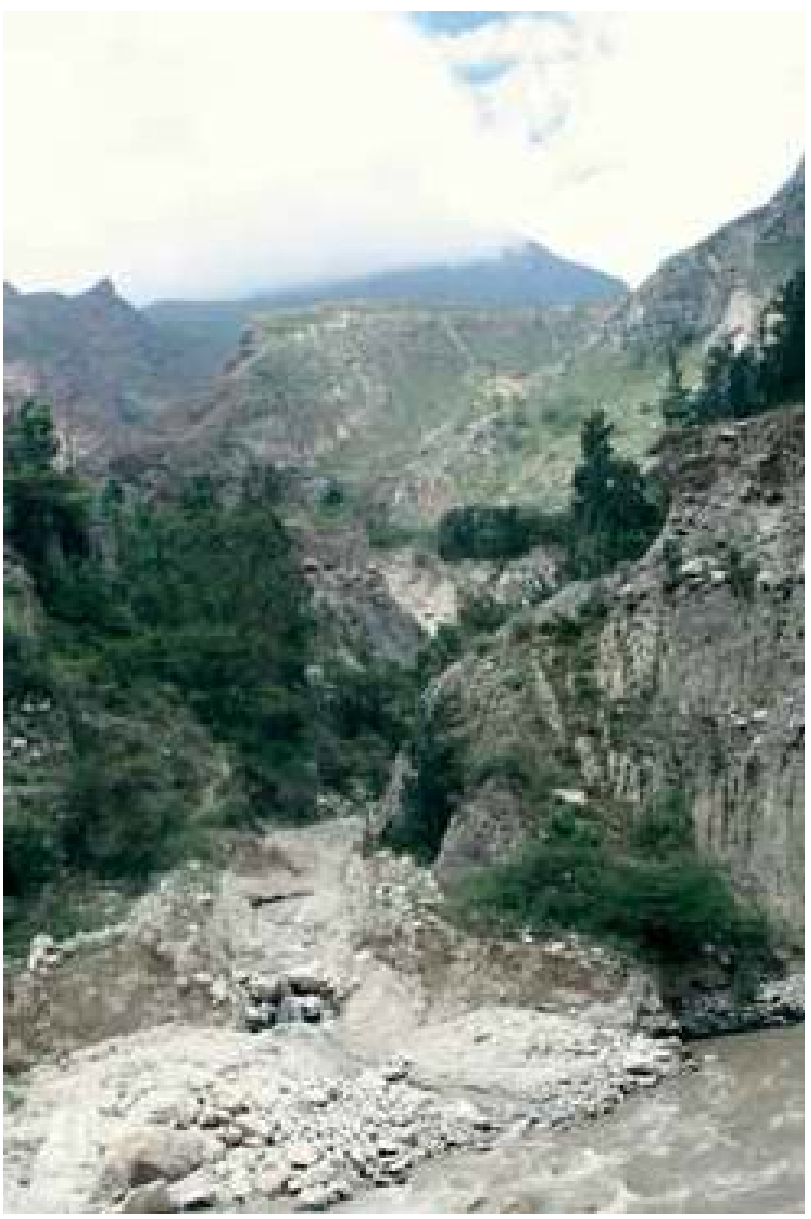

Fig. 3. Mudflow cone in the River Santa tributary inflow

(Cordillera Blanca western slope, Peru) 
for 30-40 S, it is local winter; and southward, it is local spring and summer [Budarina et al., 2000]. Mudflows appear on the Western (near Antofagasta, Chile) [Novoa, 2013] and on the Eastern Andean slope (Rio Grande basin, Jujuy province, Argentine [Garreaud, 2009]). Often, mudflows descending along tributaries, pond up the main stream with fans forming storage ponds and creating favorable conditions for bigger mudflow descent when the ponds overflow [Marcato et al., 2009].

The annual precipitation is not so much important for the fluvial and slope hazard as the precipitation rate. Even in case of the low total precipitation, an extremely unbalanced (seasonal) precipitation provides for high intensity of certain events, which results in geomorphologic damage. The schematic representations presented in Fig. 4 clearly illustrate that more than $75 \%$ of precipitation, i.e., $300 \mathrm{~mm}$, is typical for local summer (December-February) in Northern Chile, where precipitation is under $400 \mathrm{~mm} /$ year. By comparison, the typical precipitation in the Titicaca Lake basin is under $700 \mathrm{~mm} /$ year, and a little more than 50\% of this volume is accrued in the summer months, i.e., relatively comparable data are around 350-400 mm [Garreaud et al., 2003].

More unbalanced precipitation is documented on the Eastern Andean slope in the Kolanguil River basin (San Juan province, Argentina), where annual average of precipitation is less than $100 \mathrm{~mm}$. Once in 5-6 years, from 40 to $50 \mathrm{~mm}$ of rain falls in this area during one precipitation event, according to a 30-years observation cycle; the intensity of rain reaches $104 \mathrm{~mm} /$ hour [Angillieri, 2008]. A similar intensity of rainfall (about $100 \mathrm{~mm} /$ hour) is recorded on the coast of Peru [Nicholson, 2011]. As a result of such heavy rains, dry streams are filled up with water, damage floods are formed, active erosion and redeposition of channel and slope debris take place.

Physical weathering is active in arid climate where a large volume of desegregated
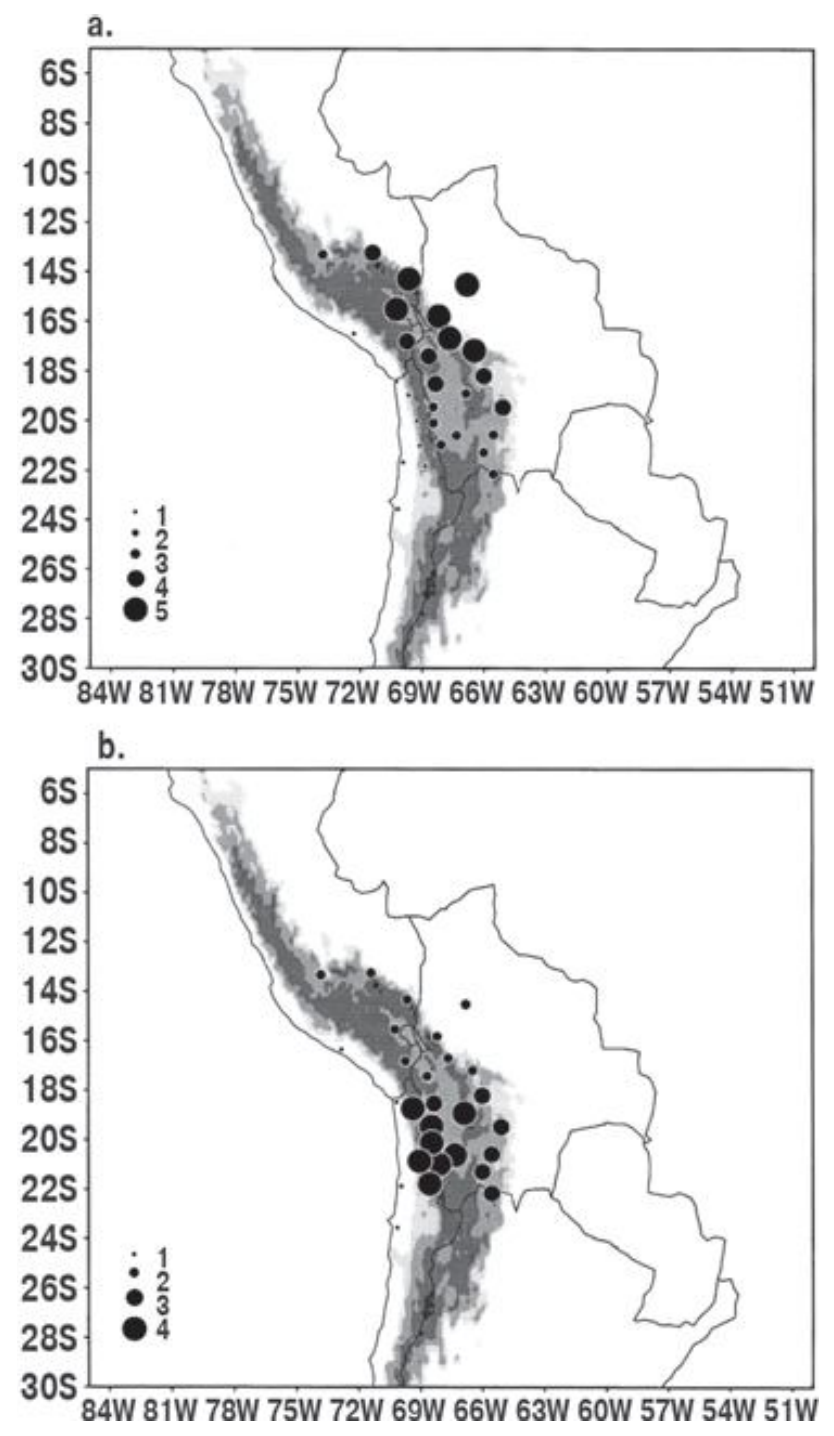

Fig. 4. Terrain elevation (shaded) and rainfall over the central Andes and adjacent lowlands. Shading begins at $2000 \mathrm{~m}$ and gets darker every $1000 \mathrm{~m}$.

(a) Rain-gauged annual mean rainfall $(\mathrm{mm})$ - size of the symbol indicates the amount of rainfall: $1-0-100$, 2-101-200, 3-201-400, 4-401-700, 5-over 701.

(b) As panel (a), but the size of the symbol indicates the fraction of annual mean rainfall (\%) concentrated in the austral summer months (December, January and February): 1 - below 50, 2-50-60, 3-60-75, 4-above 75 [by Garreaud R. et al., 2003]

rocks occurs on steep slopes not fixed with vegetation (Fig. 5). Excessive fissuring of rock zones and presence of weakly coupled volcanic rocks are conductive too. This causes extended rockslides and potential for huge debris mass-moving processes. Deficit of precipitation prevents these processes from realization, but debris avalanches appear in volcanic regions, as on the Parinakota volcano (Chile) eruption with collapse of a part of its cone [Novoa, 2013]. In case of disastrous heavy rains, debris begins to move. Giant landslides, up 


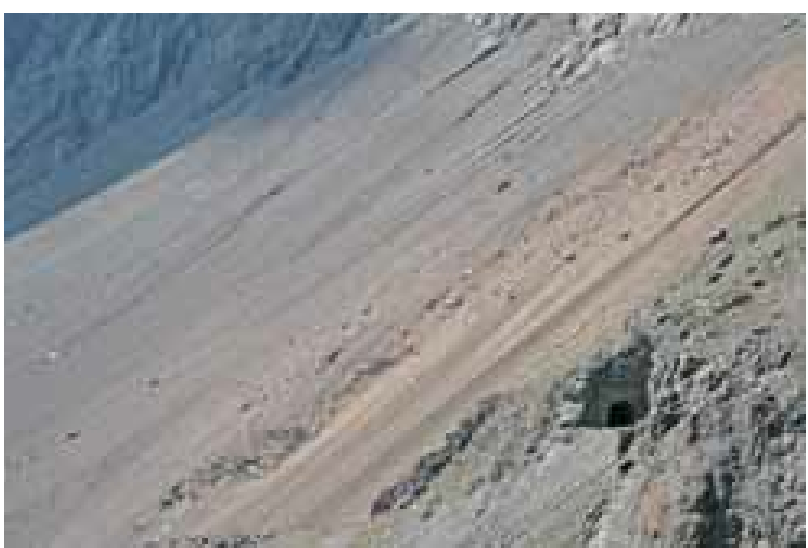

\section{Fig. 5. Rockslides in the area of Cristo Redentor (Chile-Argentinia border). The right low angle indicates the road tunnel entrance}

to several cubic kilometers, take place on slopes, lock river-streams, and form storage ponds. Sometimes, the material can almost completely overlay river terraces.

Generally, in steep-side terrain conditions, intensity of debris mass-moving increases together with precipitation, however, increase of vegetation density reduces the impact. That is why slopes above treeline are potentially hazardous. Hazards in periglacial conditions could be relevant to glacier dynamic (surge of glaciers), especially to glacial lakes and their failure.

Glaciers are more dynamic in the tropical part of the Andes and provoke negative geomorphologic processes there. For example, glaciers grow due to the influence of the Atlantic humid air mass on the Huaskaran massif (Peru). Geomorphologic disaster driven by glaciers are less common in Chile and Argentina (Aconcagua massif) due to smaller glacier dynamic as a result of much dryer the inlet Pacific and Atlantic air mass. Ice appears more like a "conserver" rather than a "provocateur" of geomorphologic disasters in temperate climate (the Patagonia plateau glacier) according to [Stillwell, 1992].

The Chilean-Argentinean and Patagonian Andes are the areas of frequent avalanche disasters [Troshkina, Kondakova, 2000]. Avalanche danger is high in all seasons here, and in the mountains of Peru, Bolivia, and Ecuador, - only in very snowy winter.
Water-and-snow flows and avalanches can be triggered by even very weak seismic tremors, i.e., only 1-3 points, but volumes of seismogenic avalanches are usually larger than normal [Kazakov, 2000].

Every 25-30 years or less frequently, ElNico acts with a tremendous force along the coastland of Peru and Northern Chile. During this period, west winds bring humid air masses that cause abundant precipitation within the otherwise dry coastland and mountains resulting in disastrous floods with run-off rise of up to 1000-3000\% [Ananiev, 1999].

Generally, the $100 \mathrm{~km}$-wide alongshore Pacific area is exposed to El-Nico; floodings is a normal occurrence in the valleys of the western Andean slope and the alongshore lowlands. Below normal precipitation is characteristic of the Altiplano during this time [Garreaud et al., 2003]. Flooding often happen in the intermountain basins, flat interstream areas (Altiplano), and valleys of the eastern Andean slope, where Atlantic air masses bring precipitation from January to March (Fig. 6). Heavy rains intensify fluvial and slope processes: landslides and creep of ground, vertical and lateral erosion, and mudslides. Observations in deep valleys on the western (Colca River, Peru) and on the eastern (Tarija River, Bolivia, and Quebrada de Humahuaca, Argentina) Andean slopes showed that huge landslides were most common during the periods of heavy rains coming after severe droughts [Codron, Cervera, 2000]. Urban and economic destruction and giant debris fans at foot-hills are the result of rainfall floods.

Arid areas face deflation and eolian accumulation. These processes occur frequently within the Pacific coastlands of Chile and Peru, in the Andean desert foothills in north-west Argentina, and on the Altiplano (Fig. 7) and the Ecuadorian paramo. Strongest winds $(20-40 \mathrm{~m} / \mathrm{s})$ are typical for the Patagonian plains. One can often see drifty sand moving up the slopes in the form of yellow streams, sometimes turning into 


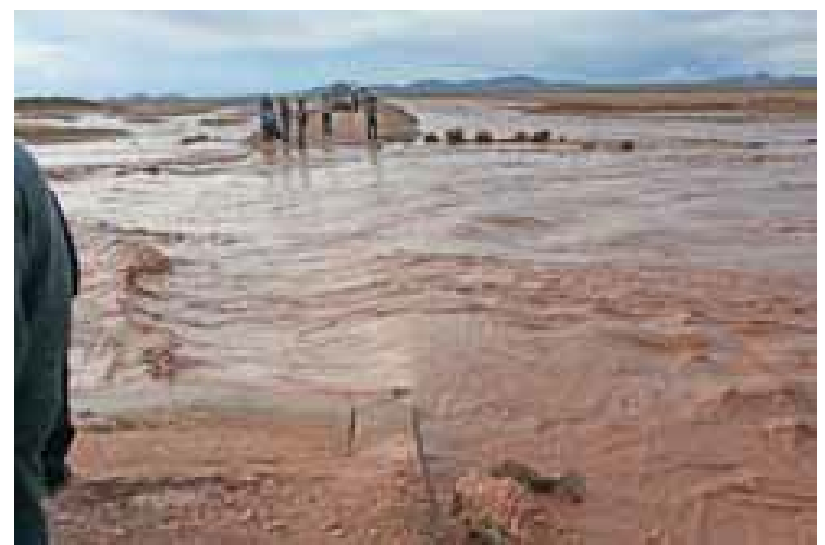

A

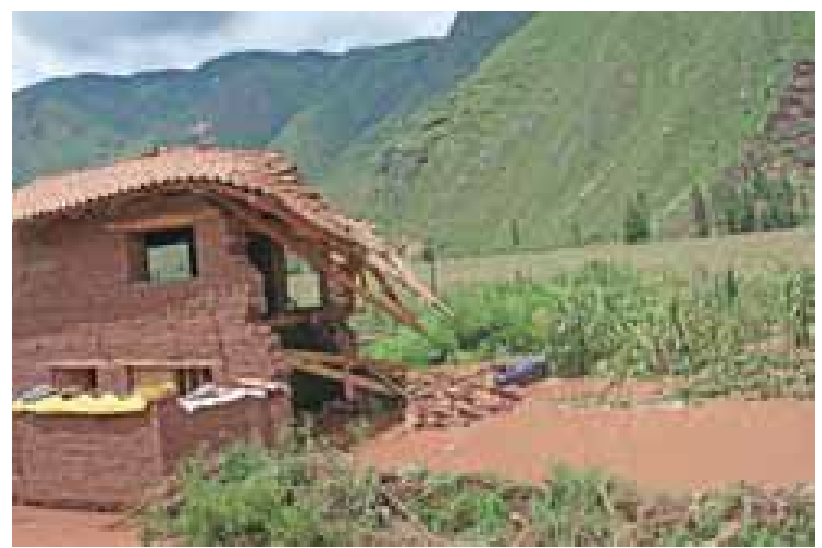

B1

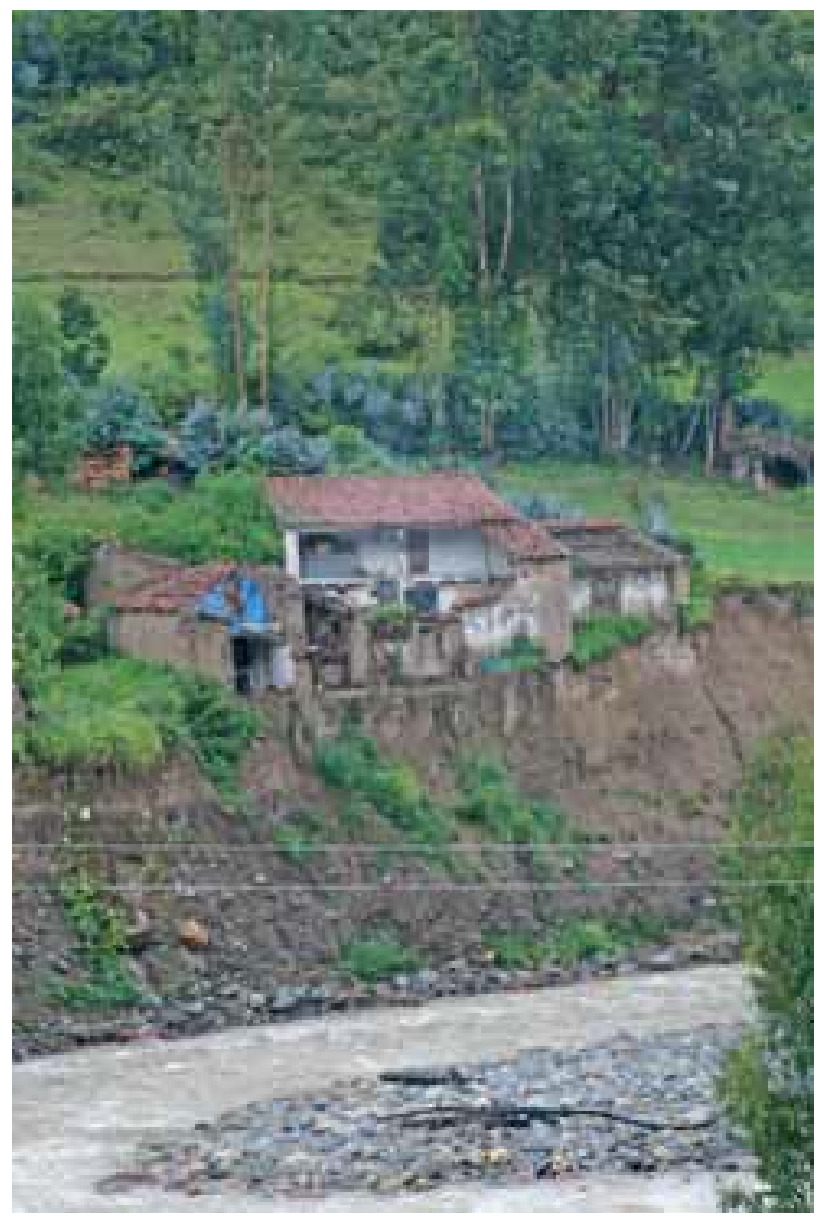

B2

Fig. 6. Flood consequences (Feb-Mar 2010).

A. Bolivian Altiplano: overflown river flooded the Tupisa-Uyuni road.

B. Peru: houses crashed by flood: 1 - the Urubamba River upper flow (the Amazon River basin), 2 - the River Santa upper flow (Pacific ocean basin) - the lateral erosion activation

sand flows, covering roads and buildings [Novoa, 1993]. Often, there are land spouts and dust storms, causing significant wind erosion [Nicholson, 2011].

Geomorphologic disasters impact adversely human life and economic activity;

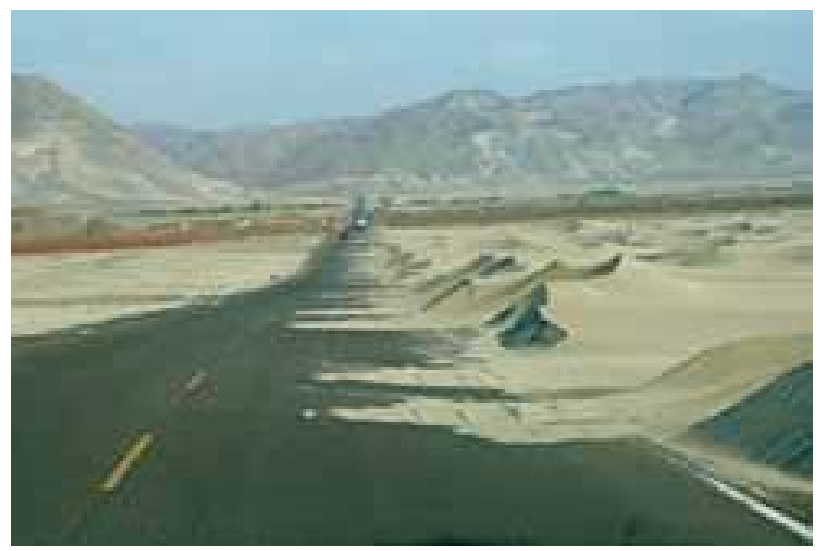

Fig. 7. Permanently moving eolian sands choke up Pan American Highway (north of Peru) however economic activity also provokes negative geomorphologic processes. For example, dam failures cause devastating consequences of flooding; moreover, increase of the population density and violation of environmental management rules increase pressure on the environmental and geomorphologic stress. Many negative processes intensify in urban areas. For example, 3 of more than 30 streams crossing Quito (Ecuador) are associated with frequent mudflows. They are caused not only by heavy rains, but also by garbage damps in their basins [Novoa et al., 1988]. During long rains, suffusion becomes active near lines of communications; funnel holes are formed within the bodies of road embankments. First of all, intense flow and landslides respond to anomalous hydrometeorological events and are active during rains within built-up and cut slopes. This is typical for 


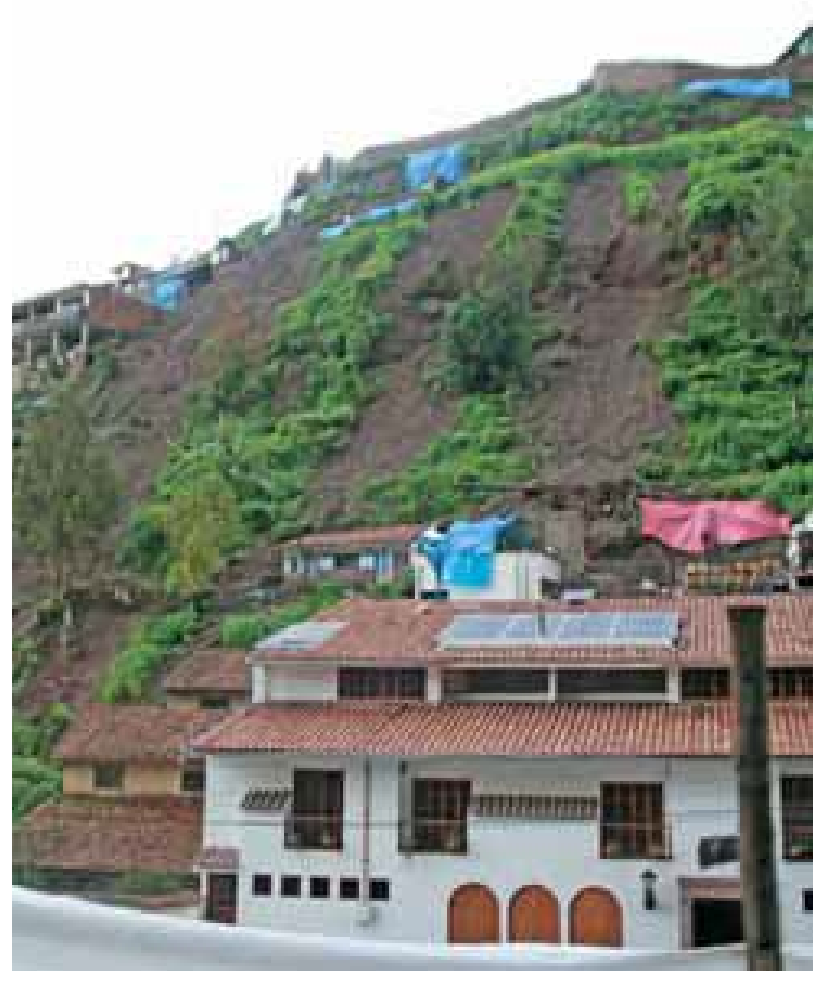

A

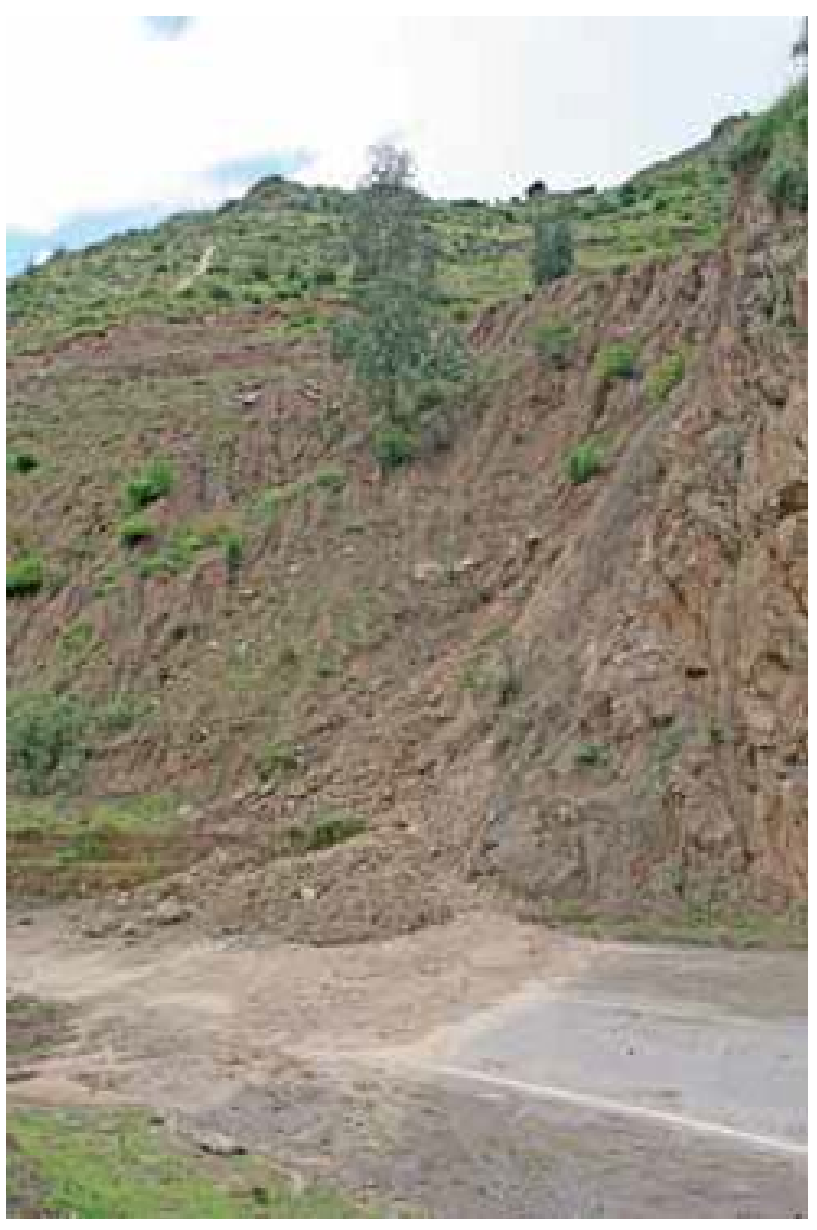

B

Fig. 8. Processes activation on cut slopes after rainfalls (Peru, March 2010):

A - earthflows at the northern part of Cuzco city, $B$-landslide-earthflow blocked the road in the Urubamba River basin

spontaneous urban development in poor outskirts situated on steep slopes (Fig. 8).

Roads and line structures are also associated with adverse impact on runoff and slope processes, resulting in events from landslides and rockslides to tropical solifluction. Mining is loosely controlled in the region and more often managed in violation of control measures [Porter, Savigny, 2002]: mining causes soil erosion, deflation, ground subsidence, ground and subsoil water level change and pollution, and slope processes activation.

Agricultural activity, e.g., slope deforestation and loss of growth as a result of overgrazing (the last one is typical for dry territories), also promotes increase of negative geomorphologic processes. Plant destruction and change of natural associations to monoculture systems create conditions for ground mass movement, erosion leading to badlands, gullying, deflation, and wind deposition [Codron, Cervera, 2000].

\section{DISASTER LOCALIZATION}

The summary of the world geomorphologic damage data [Geomorphologic hazards, 2010] shows that there are three drivers of geomorphologic hazard in mountains: tectonics, climate conditions (first of all, volume of precipitation and intensity), and human impact. The Andes are not the exception. Often it is difficult to mark the lead driver because all event-causing geomorphologic processes and their effects are interrelated. However, the efforts are under way.

Providing an overview of natural disasters in the Latin America, D. Stillwell [1992] 
Table 1. Geomorphologic hazards and disasters within the Transandean track - the north of Argentina the north of Chile (according to [Porter, Savigny, 2002])

\begin{tabular}{|c|c|c|}
\hline Region & $\begin{array}{l}\text { Natural hazards } \\
\text { and disasters }\end{array}$ & $\begin{array}{l}\text { Enhanced } \\
\text { anthropogenic factors }\end{array}$ \\
\hline Pampean Plain & Surface and linear erosion, deflation & Deforestation, plowing, grazing \\
\hline Subandian ranges & Landslides, fluvial processes, lateral erosion, gullying & Line facilities construction, mining \\
\hline Eastern Cordillera & $\begin{array}{l}\text { High seismicity, modern land uplift } 1-4 \text { mm per year, } \\
\text { landslides, locking of flows as a result of mass ground } \\
\text { displacement, disastrous floods }\end{array}$ & Line facilities construction \\
\hline Puna (Altiplano) & $\begin{array}{l}\text { Seismicity, active volcanism, high potential of cor- } \\
\text { rosion }\end{array}$ & $\begin{array}{l}\text { Open- and underground uncon- } \\
\text { trolled mining }\end{array}$ \\
\hline Western Cordillera & High seismicity, gravitational processes & Line facilities construction \\
\hline Atacama & $\begin{array}{l}\text { Active rupture tectonics, disastrous floods, mudflows, } \\
\text { high potential of corrosion }\end{array}$ & $\begin{array}{l}\text { Open- and underground uncon- } \\
\text { trolled mining }\end{array}$ \\
\hline Chilean Pacific coast & Tsunami & \\
\hline
\end{tabular}

concludes that the maximum of various widescale negative events is specific to Peru in the $X X^{\text {th }}$ century; Chile comes fourth in the list. Peru also tops the list according to the number of fatalities from earthquakes and huge landslides. This is due to location of the country at the joint of active continental plates, providing high tectonic, seismic, and volcanic activity and effect of the El-Nico phenomena.

\section{J.E. Novoa [2013] has analyzed regional} confinedness of damaging mass-movement on the Chilean slopes and marked the main factors. According to his findings, geomorphologic damages within the northern and central parts of Chile are caused, primary, by enormous hydrometeorological events (El-Nico). The negative effect of deforestation is strongly marked in the central and southern parts of Chile. Seismic events influence also grows stronger in the northern part. According to S. Zavgorodniaya's findings [1996], primary seismic-and-tectonic and volcanic processes govern the extreme character of geomorphologic processes within the territory of Ecuador. The role of landscape-and-climate conditions increases within plains and foothills.

\section{Porter and K. Savigny [2002] undertook} a study of natural disasters for the purpose of laying a pipeline along the following transect: from the Pampean Plain, through the Subandian ridges in Argentine, Eastern and Western Cordilleras parted by the
Bolivian Altiplano, and, then, through the Atacama to the Pacific coast of Chile. According to this study, we have isolated the reported geomorphologic processes of the subregions (Table 1).

We also carried out analysis of geomorphologic hazards and disasters confinedness to the main Andean parts: slopes, valleys, flat interstream areas, submountain and intermountain plains with low hills, the Pacific coast, and large lakes (Table 2). The above-mentioned data and our own observation results allowed us to compile a sketch map of the Central Andean part zoning considering special aspects of geomorphologic hazard and damage development (Table 3, Fig. 9). Sixteen areas with different spectra of the dominant catastrophic processes were identified.

Then, we can deduce that slopes, valleys, submountain and intermountain plains, and the Pacific coast are characterized by specific range of geomorphologic hazard, broadly speaking, by active denudation caused, primary, by a wide range of erosion and gravitational processes. As a result, large volumes of debris are moving towards submountain plains and the ocean trench. High seismicity of the territory is conductive to processes intensity increase.

Central parts of vast flat interstream areas develop apart from the main base level 


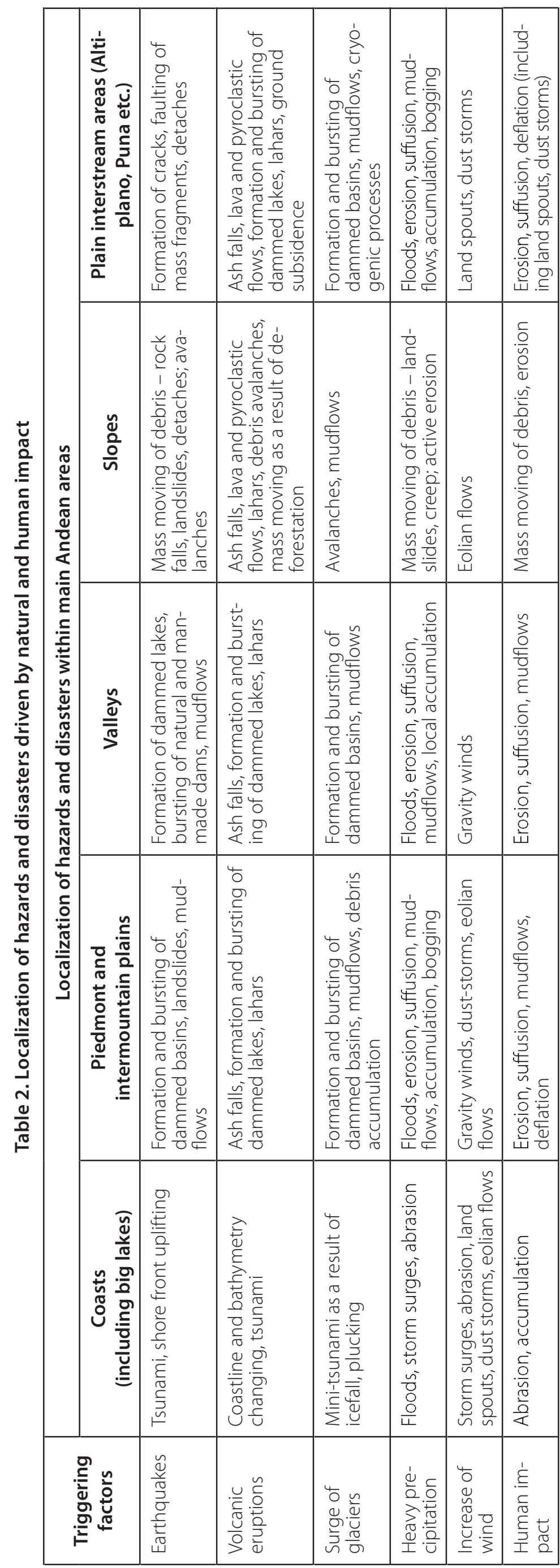

defining specific range of associated processes. These are not only various examples of denudation (particularly, erosion and deflation) but also accumulation related to local flooding, local river network transformation, and change of volcanic and glacier dynamics in some cases. Gravitational and seismic-and-gravitational processes and erosion leading to deep canyons and badland are active peripherally.

Analysis revealed that certain geomorphologic processes are not so hazardous by themselves, but their combination and interaction and intensity of conductive factors increase the risk of disasters [Lebedeva, 2013]. Frequently, a chain of extreme processes and their sequence and combination lead to huge disasters e.g., the Yungay event (Chile), where seismic shock caused a landslide followed by a mudflow. There is also the Parraguirre event in the Colorado valley (Santiago region), where rocky slide transformed into debris avalanche that, in turn, after $5 \mathrm{~km}$, transformed into mud-and-stone flow because of melting of included ice; the height of flow frontal wave reached 20-30 m [Novoa, 2013]. The 1987 earthquake in Ecuador caused numerous slumps in the Cordillera Real, and heavy rains caused disastrous mudflow in the Salado-Coca valley resulting in transport of 0,08 cubic kilometers of debris, pipe line, and highway destruction within $100 \mathrm{~km}$. The Hosefina landslide in the Paute valley in 1993, was also complicated [Zavgorodniaya, 1996]: it was caused by both heavy precipitation and human impact (slope cutting in case of cropping).

The Chaiten eruption in 2010 was responsible not only for descent 

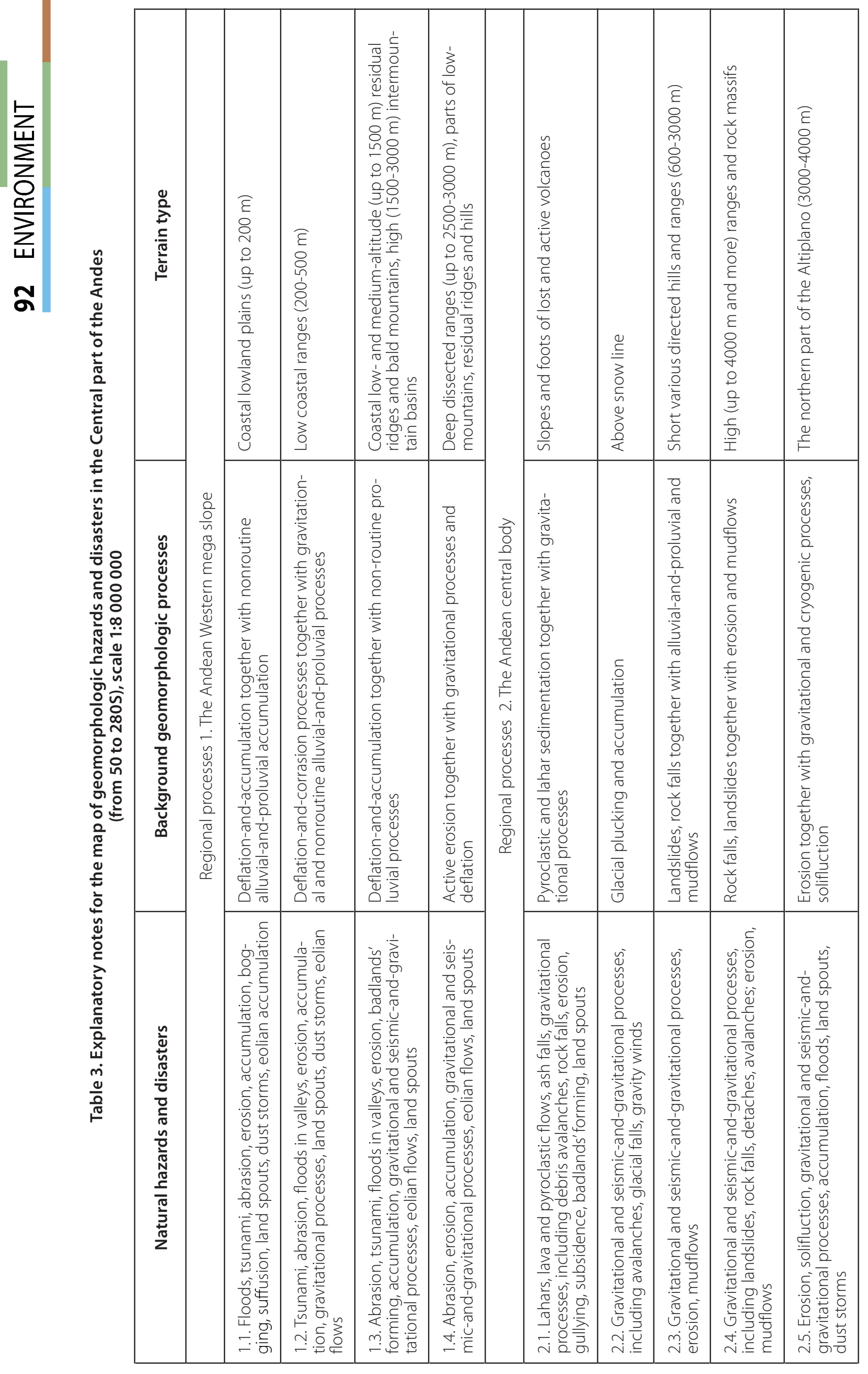


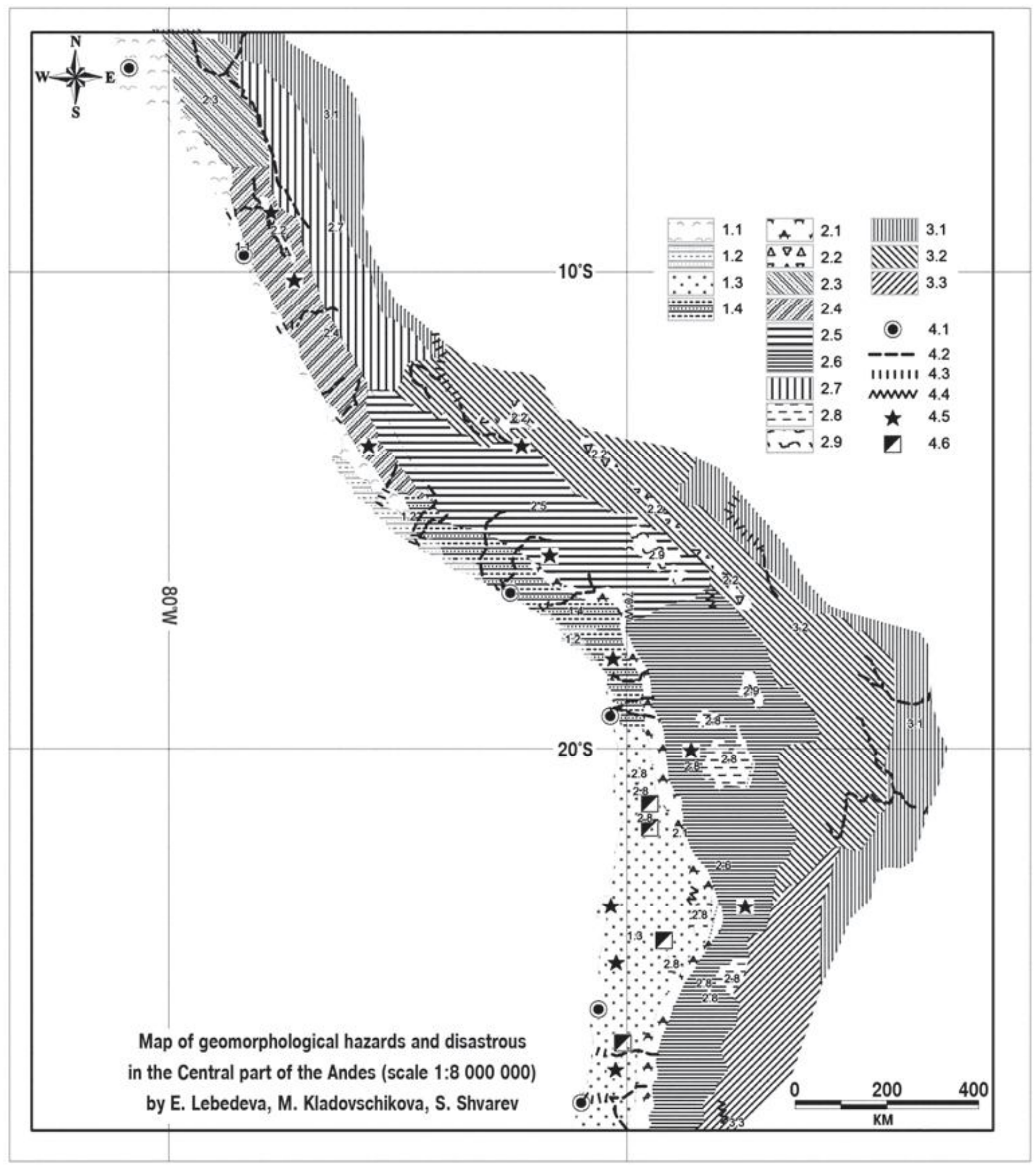

Fig. 9. Map of geomorphologic hazards and disasters in the central Andes sector (from $5^{\circ}$ till $28^{\circ}$ s.l.). Map symbols see Table 3

of lahars but also for vegetation destruction within the adjacent slopes. This fact allows us to forecast the extent of potential damage from mass movement, the most probable consequences of earthquakes. However, abundance of precipitation conductive for restoration of vegetation cover should mitigate the risks within 5-7 years in the region.

\section{CONCLUSION}

Geological-and-tectonic and physiographical features of the South American Pacific coast are associated with high intensity of morpholitogenesis including disastrous paths of some geomorphologic processes. Their combination and interaction and intensity of conductive factors increase the risk of disasters. The Andean natural disasters, 
such as volcanic eruptions threatening ashbound cities and fields, earthquakes causing avalanches and mudflows destroying human settlements, large flooding in mountains breaking highways and destroying villages and farm lands, are responsible for significant economic damage now and in the past.

Human economic activity makes considerable contribution to environmental transformation in the way of additional activation of many natural processes. Human impact enhances development of natural disasters. For example, cutting of slopes, deforestation, and desert advancement as a result of overgrazing bring negative consequences. Slope processes, erosion, and deflation (in dry areas) intensify. Mining causes soil erosion and surface and ground water pollution.

Thus, terrain-forming processes are influenced by many natural and human drivers that provoke high intensity of geomorphologic processes. Thereby terrain morphology and rock lithology, precipitation type, and vegetation conditions influence the character and intensity the terrain-forming processes. Large hydrometeorological events, frequent seismic shocks, volcanic eruptions, and human impact intensify disasters development.
The South American Andes extension allows drawing out principles of geomorphologic disasters of these continental marginal mountains in various natural zones from temporal to subequatorial latitudes that are characterized by the unique individual features, e.g., heat-moisture ratio, that governs both typical and extreme geomorphologic processes. An important feature of the study area is the asymmetric distribution of geomorphologic processes within the coastal and inland slopes of the mountain system, as well as latitudinal zoning of this distribution. Mapping with quantitative assessment of intensity of potential natural and human impact is necessary for understanding of principles of areal distribution of geomorphologic stress in the region and defining the zones of potential risk of disasters development.

\section{ACKNOWLEDGMENTS}

Authors are grateful to G.S. Ananiev (Faculty of Geography, Lomonosov Moscow State University), S.S. Zavgorodniaya (Pontifical Catholic University of Ecuador) and V.P. Chichagov (Institute of Geography, Russian Academy of Sciences) for data and valued opinion about the issues discussed in the paper. Special thanks to S. Shvarev for assistance with map material.

\section{REFERENCES}

1. Aleksandrov S.M. (1996). Nonlinear nature of the relief-forming processes and extreme situations // Moscow: RFBR, 112 p. (in Russian with English summary).

2. Alvarado P., Beck S. (2006). Source characterization of the San Juan (Argentina) crustal earthquakes of 15 January 1944 (Mw 7,0) and 11 June 1952 (Mw 6,8) // Earth and Planetary Science Letters. N 243 (3-4). P. 615-631.

3. Ananiev G.S. (1998). Catastrophic relief-forming processes // Moscow: MSU Publishing House, 101 p. (in Russian).

4. Ananiev G.S. (1999). Exogenous processes at the north-west of South America during ElNino 1997-1998 // Proceedings of the Russian Geographic Society. Vol. 131, Issue 4, pp. 18-25. (in Russian). 
5. Angillieri M.Y. (2008) Morphometri analysis of Colangbil river basin and flash flood hazard, San Juan, Argentina // Environ Geol. N 55. P. 107-111.

6. Budarina O.I., Perov V.F., Sidorova T.L., Belaya N.L. (2000). Genesis and regime of mudflows in South America // Records of Glaciological Studies, Iss. 88, pp. 50-55. (in Russian with English summary).

7. Cembrano J., Lara L. (2009). The link between volcanism and tectonics in the southern volcanic zone of the Chilean Andes: a review // Tectonophysics, N 471, pp. 96-113.

8. Charrier R., Hŭrail G., Pinto L., Garcha M. et al. (2013). Cenozoic tectonic evolution in the Central Andes in northern Chile and west central Bolivia: implications for paleogeographic, magmatic and mountain building evolution // Intern. Journ. of Earth Sciences (Geol Rundsch). N 102. P. 235-264.

9. Codron J.C., Cervera F.S. (2000) Riesgos naturals en Los Andes: cambio ambiental, percepciln y sosteniilidad // Boletin de la A.G.E.N. N 30. P. 69-84.

10. Enman V.B. (1973). Modern Earth crust movements and earthquakes // Modern Earth crust movements. Tartu: Estonian SSR Academy of Science, pp. 633-642. (in Russian)

11. Garreaud R. (1992). Impacto de la variabilidad de la lunea de nieve en crecidas invernales en cuencas pluvio-nivales de Chile Central // XI Congreso Chileno de la Sociedad Chilena de Ingenierнa Hidrбulica, Santiago. 15 p.

12. Garreaud R. (2009). The Andes climate and weather // Advances in Geosciences. N 22, pp. 3-11.

13. Garreaud R., Vuille M., Clement A.C. (2003). The climate of the Altiplano: observed current conditions and mechanisms of past changes // Palaeogeography, Palaeoclimatology, Palaeoecology. N 194, pp. 5-22.

14. Geomorphologic hazards and disaster prevention (2010). Ed. Alc6ntara-Ayala I., Goudie A. Cambridge: University Press. 291 p.

15. Golubev G.N. (1969). Chile rivers nourishment // MSU Bulletin. Series 5 - Geography, N 2, pp. 36-41. (in Russian with English summary).

16. Gotvanskiy V.I., Lebedeva E.V. (2010). Natural and anthropogenic factors influence on geomorphologic processes intensity in the Far East // Geomorphology, N 2, pp. 26-36. (in Russian with English summary).

17. http://inosmi.ru/infographic/20111226/181319543

18. http://finam.info/need/news2478800001

19. http://www.ncedc.org/anss/catalog-search.html

20. http://www.volcano.si.edu/world 
21. Kazakov N.A. (2000) Possible mechanism of formation of seismogenic avalanches // Records of Glaciological Studies, Iss. 88, pp. 102-106 (in Russian with English summary).

22. Kladovschikova M.E. (2008). Relief development and relief-forming processes of marginal continental mountains (the Andes case) // Author's abstract of a thesis, Moscow: MSU Geographic department, p. 24. (in Russian with English summary).

23. Korotkiy A.M., Korobov V.V., Skrylnik G.P. (2011). Anomalous natural processes and its influence on geosystems stability in the south of Russian Far East //Vladivostok: Dalnauka, 265 p. (in Russian with English summary).

24. Lebedeva E.V. (2013). Natural and anthropogenic basis of geomorphologic processes intensity in the Andes // Geomorpology, N 4, pp. 58-71 (in Russian with English summary).

25. Levin B.W., Sasorova E.V. (2009). Latitudinal distribution of earthquakes in the Andes and its peculiarity // Advances in Geosciences. N 22, pp. 139-145.

26. Lukashova E.N. (1958). South America // Moscow: Uchpedgiz, 467 p. (in Russian).

27. Marcato G. , Pasuto A., Rivelli F.R. (2009). Mass movements in the Rio Grande Valley (Quebrada de Humahuaca, Northwestern Argentina): a methodological approach to reduce the risk // Advances in Geosciences. N 22, pp. 59-65.

28. Montgomery D.; Balco G., Willett S. (2001). Climate, tectonics, and the morphology of the Andes // Geology. N 29 (7), pp. 579-582.

29. Nicholson Sh.E. (2011). Dryland climatology. Cambridge Univ. Press. 516 p.

30. Novoa J. E. (1993). Eficacia geomorfolygica sistema de playas y dunas Bahнa de Coquimbo (IV Regiyn, Chile sembrido): discusion metodolygica y resultados // Anales Sociedad Chilena de Ciencias Geogr6ficas. N 1, pp. 26-33.

31. Novoa J.E (2013). Mass land movements on slopes and its influence on the Western Andes morphogenesis (Chile) // Geomorpology, N 2, pp. 81-96. (in Russian with English summary).

32. Novoa J.E., Araya A.A., Fernбndez R.M., Araya M.C. (1995). Potential tsunami effects in La Serena area North-Central Chile / Late Quaternary coastal records of rapid change: Application to present and future conditions. Chile, Antofagasta. 12 p.

33. Novoa J. E., Meza M., Moreno l. et al (1988). Anбlisis morfodinб́mico aplicado al diagnystico de riegos naturales en los sistemas de La Gasca y San Carlos (Quito, Ecuador) // GeografHa y Desarrollo. N 2, pp. 303-330.

34. Pararas-Carayannis G. (1974). An investigation of tsunami source mechanism off the coast of Central Peru // Marine Geology. V. 17. Amsterdam: Elsevier. P. 235-247.

35. Perov V.F. (2012). Mudflow studies // Moscow: MSU Geographic department, 272 p. (in Russian). 
36. Phillips J. (2011). Emergence and pseudo-equilibrium in geomorphology // Geomorphology. N 132 (3-4), pp. 319-326.

37. Porter M., Savigny K.W. (2002). Natural hazard and risk management for South American pipelines // Proceedings of IPC 2002: $4^{\text {th }}$ International Pipeline Conference. Calgary, Canada. IPC02-27235. 8 p.

38. Rantsman E.Y., Glasko M.P (2004). Morphostructural centres - places of extreme natural phenomena // Moscow: Media-PRESS, 223 p. (in Russian).

39. Sergio A. Sepblveda, Alejandra Serey, Marisol Lara. et al. (2010). Landslides induced by the April 2007 Aysŭn Fjord earthquake, Chilean Patagonia. Landslides N 7, pp. 483-492. DOI 10.1007/s10346-010-0203-2.

40. Stillwell D. (1992). Natural hazards and disasters in Latin America // Natural Hazards. N 6, pp. 131-159.

41. Tectonic Evolution of South America (2000) // $31^{\circ}$ Intern. Geol. Congress, Rio de Janeiro. 650 p.

42. The Andes: Active Subduction Orogeny. (2006). Springer-Verlag Berlin Heidelberg. 440 p.

43. Tilling R. I. (2009). Volcanism and associated hazards: the Andean perspective // Advances in Geosciences. N 22, pp. 125-137.

44. Troshkina E.S., Kondakova N.L. (2000). New data on the avalanche mode mountainous areas of the Southern Hemisphere // Records of Glaciological Studies, Iss. 88, pp. 92-101 (in Russian with English summary).

45. Ufimtsev G.F. (2011). Andes diary (relief and morphotectonics of the Peruvian Andes) // Moscow: Scientific World, 164 p. (in Russian).

46. Zhidkov M.P. (1985). Morphostructure of continental-oceanic suture zones of Pacific Rim concerning powerful earthquakes places forecast (Kamchatka, west of South America) // Author's abstract of a thesis. Moscow: IG RAS, 27 p. (in Russian).

47. Zavgorodnaya S.S. (1996). Modern geomorphologic processes and its inventory for ecologic and commercial purposes in Ecuador // Author's abstract of a thesis. Moscow-Quito: MSU, 43 p. (in Russian).

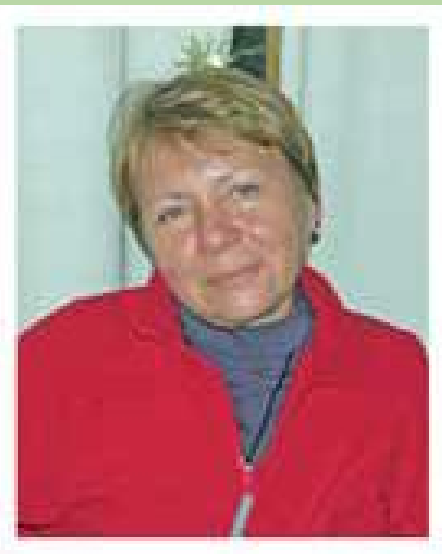

Ekaterina V. Lebedeva is Senior Researcher of the Laboratory of Geomorphology of the Institute of Geography RAS. She graduated from the Lomonosov Moscow State University and received PhD in 1992. Her scientific interest: relief evolution in changing natural conditions and under the influence of anthropogenic factors, intensity of geomorphological processes, ecologicgeomorphological problems. Regions of Research: Far East and European Russia, South and East Africa, South and Central America, Australia. She is the author of approximately 100 scientific papers. 


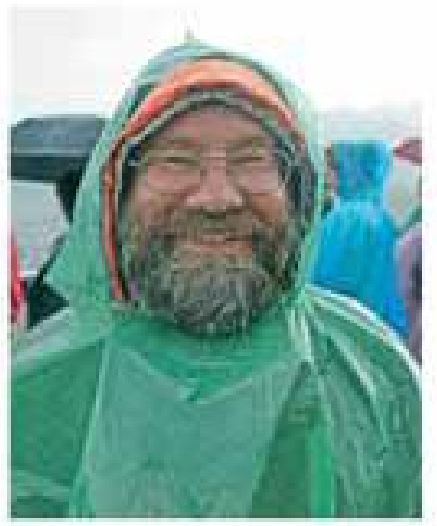

Dmitry V. Mikhalev is Senior Researcher of the Laboratory of Geoecology of the North of the Lomonosov Moscow State University. He received his PhD in 1990. The area of his scientific interest:isotope geocryology, paleogeography, paleoclimatology, cryogenic processes, and geoecology. The regions of research: Russian Arctic, South Africa, South and Central America, Australia. $\mathrm{He}$ is the author of approximately 70 scientific papers.

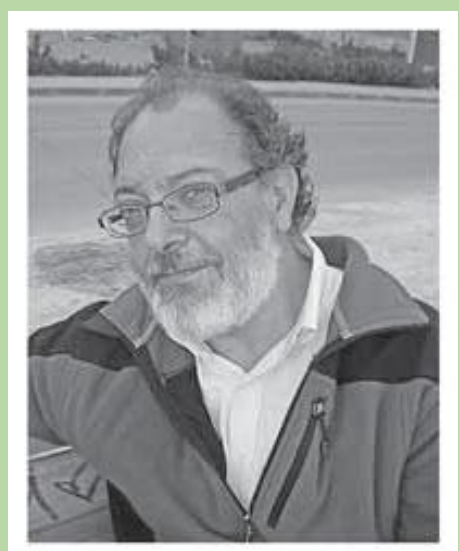

José E. Novoa Jerez, PhD, is Professor in Physical Geography, University of La Serena, Research Member of the Center for Advances Studies in Arid Zones (CEAZA-Chile), Chair of Applied Physical Geography Program, and Steering Member of the Risk and Natural Disaster Chapter of the International Geography Union (IGU). His research interests are in applied physical geography (from local to regional scale) related to natural hazards, climatic change, applied climatology, and natural resources planning in arid environments. Dr. Novoa has had a long career in research and teaching in physical geography in South America. During last two decades, he was responsible for the research development and operational implementation of theoretical models and studies in arid environments related to physical geography oriented to urban and rural planning strategies in mountain, coastal, and fluvial ecosystems of Chile, Argentina, Peru and Bolivia.

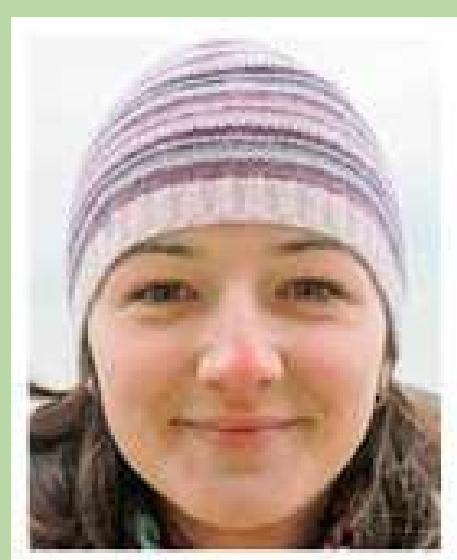

Mariya E. Kladovschikova is Researcher of the Department of Geomorphology of the Institute of Geography of Russian Academy of Sciences. She obtained her PhD from the Lomonosov Moscow State University in 2008 under supervision of Professor G. Anan'ev on terrain processes development in marginal continental mountains of the Andes. She joined the staff of the Institute of Geography in 2009. Her academic interest encompasses geomorphologic hazard in dynamic mountainous ranges, anthropogenic geomorphology, and cultural landscapes and is supported by her professional experience in Khibiny, Greater Caucasus, South Urals, Crimean Mountains, Andes, and Sino-Tibetan Mountains. 